Received $\quad 07.05 .2018$

Reviewed $\quad 18.10 .2018$

Accepted 24.10.2018

A - study design

B - data collection

C - statistical analysis

D - data interpretation

E - manuscript preparation

$\mathbf{F}$ - literature search

\title{
The optimal position of a pumping station in the mining area based on the digital terrain model
}

\author{
Marian PONIEWIERA ${ }^{1)}{ }^{A B C D} \bowtie$, Iwona JELONEK ${ }^{2) ~ E F}$, \\ Wioleta BLASZCZAK-BĄK ${ }^{3) \text { EF }}$
}

1) orcid.org/0000-0003-0855-7105; Silesian University of Technology, Faculty of Mining and Geology, Akademicka 2a, 44-100 Gliwice, Poland; e-mail: Marian.Poniewiera@polsl.pl

2) orcid.org/0000-0002-9876-9007; University of Silesia, Faculty of Earth Science, Katowice, Poland; e-mail: iwona.jelonek@us.edu.pl

3) orcid.org/0000-0001-6169-1579; University of Warmia and Mazury, Faculty of Geodesy, Geospatial and Civil Engineering, Olsztyn, Poland; e-mail: wioleta.blaszczak@uwm.edu.pl

For citation: Poniewiera M., Jelonek I., Błaszczak-Bąk W. 2019. The optimal position of a pumping station based on the digital terrain model. Journal of Water and Land Development. No. 40 (I-III) p. 103-111. DOI: 10.2478/jwld-2019-0011.

\begin{abstract}
The purpose of the work described in the article was to find the optimal location of the pumping station for the mining area Krzyżowice III Hard Coal Mine "Pniówek". Mining exploitation causes lowering of the area and changes in water relations. Hence, it is necessary to perform a gravitational, and if it is impossible, forced outflow of water. Localization of the pumping station should assure removal of excess water and prevent flooding. Not only was the present relief taken into account, but also the entire period of the mine's existence. On the basis of the results of airborne laser scanning a digital terrain model (DTM) was generated. Then a catchment division was made for the entire analyzed area. The article presents the workflow of performing the simulation as the area will be changed due to forecasted mining operations. A practical way to solve the problem of simplifying large amounts of data was also shown. The obtained source materials were developed with the use of the Geolisp software. The system operates in a CAD graphic environment and allows for automation of the most frequently performed works in the field of mining map preparation. The Geolisp cooperates with EDN-OPN program. Thanks to this fact it is possible to combine the obtained results of calculations of predicted deformations of the mining area and the rock mass with the digital map.
\end{abstract}

Key words: AutoCAD Civil, Digital Terrain Model, laser scanning, mining surface deformation

\section{INTRODUCTION}

As a result of mining, voids have been forming in the rock mass. The forces of gravity cause slow motion of rock masses and soil towards the excavation and empty spaces are compressed. When there is a roof failure, the roof layers break down directly above the selected space and fill existing voids with them. The rock-filled rock rubble has a larger volume than the rock from which it formed. The upper layers of the rock leaning against it undergo deflection, which is getting smaller the closer it is to the surface, but then occurs on a larger area [BIAŁEK 2003].
The direct impact of mining operations on the surface is the formation of continuous and discontinuous deformations. They are accompanied by indirect influences resulting from changes of water relations in the rock mass (water damage, drying, tremors, leaching, depression due to drainage of the rock mass).

The term continuous deformation" is understood as a gentle depression of the ground in the form of pits (this is the most common direct impact on the surface area). They do not cause a clear violation of cohesiveness of rocks, in contrast to discontinuous deformations, which may occur in the form of gaps, frets or sockets. 
As a result of mining exploitation, a floodplain may occur. Landfalls created because of mineral extraction can result in the formation of no-drainage pits. On the other hand, inhomogeneous landslides may cause that a section of the watercourse starts to rise at a certain distance, which may change the stream's bed or a floodplain may arise. The problem with floodplain was described for example by GHARBI et al. 2016. In this paper authors presented show the benefits and limitations of tested models in flood forecasting. Their analysis of the results showed a good agreement between $1 \mathrm{D}$ and $2 \mathrm{D}$ models and that the reliability of results depends strongly on the accuracy of available data. In another paper [HARTNETT, NASH 2017], authors developed MSN Flood system. This is a multi-scale nested modeling system, developed through the novel treatment of nested boundaries as internal computational boundaries. The main focus of the development of MSN Flood was to develop a highly accurate model that would be computationally efficient and had the potential to be applied to any urban coastal floodplain.

The size of deformation is influenced by many factors, including the depth of exploitation, the thickness of the deposit being exploited, the way of filling the resulting void, the shape and size of the selected area, compactness of the rock above the deposit, occurrence of faults, deck inclination and others. Their large number makes it difficult to analyze and forecast the effects of mining operations.

The aim was to develop a comprehensive technology including both creation of operation data directly on the basis of the Digital Model of the Deposit, development of the predicted surface area as well as implementation of various calculations, such as determination of floodplains. The literature on the subject is very rich in terms of workflow used, while practical experience shows that a proper preparation of source data is also important.

\section{STUDY AREA AND METHODS}

\section{DESCRIPTION OF USED SOFTWARE}

In Polish underground mines, the most popular software is Geolisp - a system for creating and servicing digital mining maps [GEO-LISP 2018; JELONEK et al. 2015; PONIEWIERA 2017]. This is the original program created by Marian Poniewiera. The aim of the software is to automate the most frequent works in the field of preparation of mining maps. It contains several thousand symbols for survey, ventilation, geology, transportation, rail, urban planning etc.

The Geolisp system works in a CAD environment, such as AutoCAD, BricsCAD etc. The system can semiautomatically create derivative maps on the basis of the maps with different scales and contents. It can generate automatically a 3D model based on a flat map. An analysis, technical documentation creation and construction of a numerical deposit model are also possible. For the majority of mines, coefficients of transformation between local and national coordinate systems have been developed. A free MP_NMT tool can be used for DTM creating and controlling, isolines generation, plotting, volume calculation, etc. [GEO-LISP 2018].
The EDN is a package of programs for prediction of mining ground deformations. It is the original program developed by Jan Białek [BIAŁEK 2003]. It calculates the impact of planned production on the rock mass and the ground surface. The results of these calculations, obtained in the form of text databases, can be combined with a digital map using the Geolisp system. Thanks to this, it is possible to: make a topology of buildings, detect and colour the objects whose category of resistance is lower than the category of influence. Geolisp can add DTMs of ground surface and dips. Then the software calculates areas which can be flooded.

\section{DESCRIPTION OF THE TEST AREA}

The research area was the mining area of Krzyżowice III Black Coal Mine "Pniówek". The deposit covers an area of $28.5 \mathrm{~km}^{2}$ and it is located in the southern part of the Silesian Voivodeship.

It includes 5 settlements, most of the area is covered by agricultural land and forest. The test area is poorly diversified, it is characterized by flat elevations and it is cut by relatively deep erosive valleys. The lowest-lying areas are connected with the historical course of the Parmina River, reaching an elevation of $+255.0 \mathrm{~m}$ above sea level.

In the majority of the area, absolute heights are within the limits of $265.0-275.0 \mathrm{~m}$. In terms of the hydrographic network the test area is varied and belongs to the basin of the Vistula and Odra rivers. Line watershed level 2 separating the left-bank tributaries of the Vistula: the Pszczynka and the Potok Hynek (the Stream Hynek), runs through the central part of the test area. The volumes of surface water flow are controlled at 13 measuring points.

The airborne laser scanning was performed in April 2016. The measurement was made by means of the Lite Mapper scanning system LMS6800, digital camera, Hasselblad 39/50 megapixel and the system GPS/IMU Areo CONTROL. The altitude of the flight was $650 \mathrm{~m}$, and the density scanning was 4.8 pts per $\mathrm{m}^{2}$. The measurement data set consisted of 54 files and contained over 226 million points.

\section{LASER SCANNING DATA PROCESSING}

Introduction. Nowadays, surveyors and engineers in geodetic centers and mines deal with data coming from laser scanning [KUZIA 2016; SOKOŁA-SZEWIOŁA, WIATR 2014].

Usually it includes: reading a point cloud, creating a Digital Terrain Model based on it, generating contours, calculating volume, etc.

The implementation of these tasks in AutoCAD Civil $3 \mathrm{D}$ is here briefly discussed.

Reading point cloud. It is convenient to enable the panel "Point Cloud" in the tab "Insert". We indicate in it the position of Autodesk ReCap and select the data file. ReCap loads files in various formats: LAS, plain text file $\mathrm{XYZ}$ and others. Loading a point cloud from a LAS file is shown in Figure 1. 

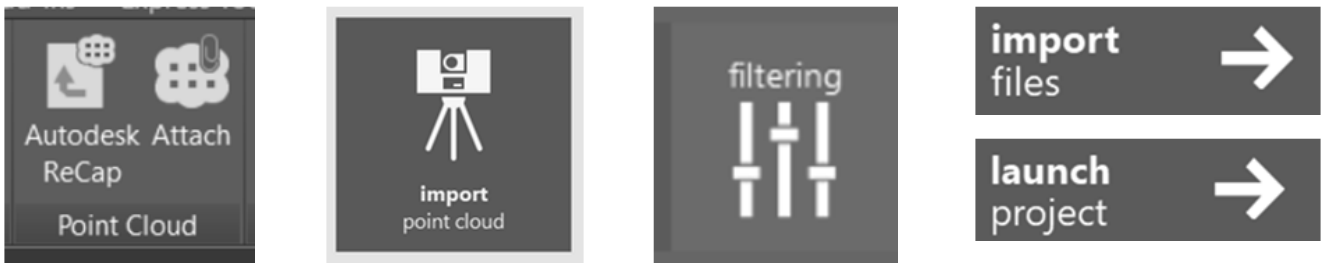

Fig. 1. Loading a point cloud from a LAS file; source: own elaboration

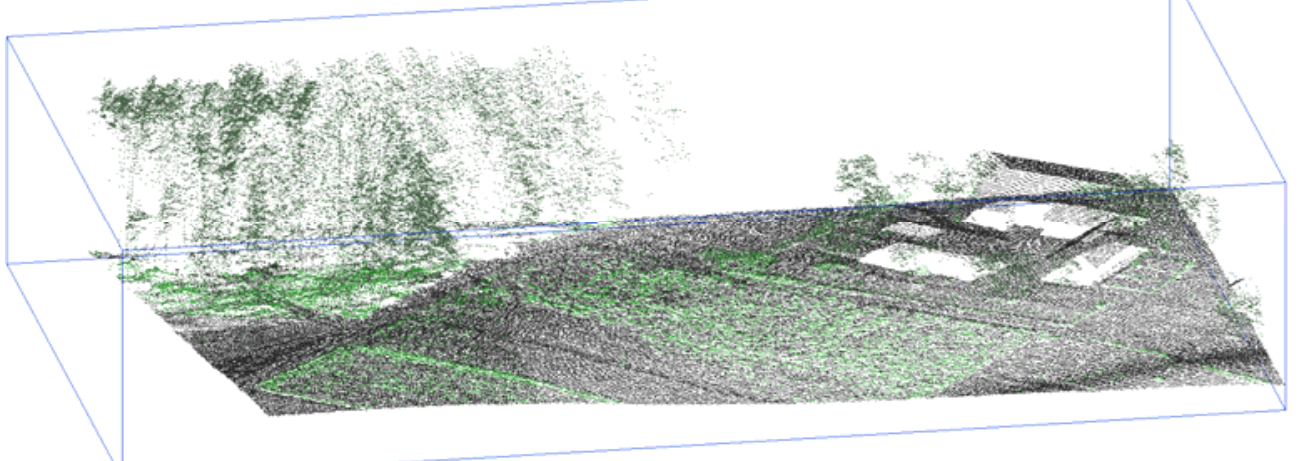

Fig. 2. Spatial visualization of point clouds; source: own elaboration

The style of the point cloud. While loading data or later on (indicating the point cloud created in the "tool area"), we can change the style of the point cloud, e.g. specify that the high vegetation points are loaded on the Tree layer, and the ground points on the Terrain layer. This is important because DTM should be created only on the basis of the ground points. In the style of a point cloud, we can determine the color and size of the displayed point. Spatial visualization of point clouds is shown in Figure 2.

Creating and simplifying the TIN (triangular irregular networks) surface. The TIN surface is a grid of triangles with vertices at the measuring points [JELONEK et al. 2015]. To transform a point cloud into the surface of the TIN triangles, we indicate the point cloud in the "tool area" and select "Add points to the surface". Having a TIN surface, we can interpolate the contours, calculate the volume and generate cross-sections. AutoCAD deals with many millions of points, but the created TIN surface should be simplified, because then the pace of work will increase significantly and the isolines will be smoother. The simplification with the AeccSimplifySurface command consists in removing a certain number of points, e.g. $99 \%$ of such points, whose height difference between neighboring points does not exceed the given value, e.g. $0.10 \mathrm{~m}$. Additional information on simplification is given in chapter "Tin surface simplifying".

Generation of isolines. In the "tool space" we indicate "Surface style" and in the "Layers" tab we define the pitch, color and method of smoothing the isoline. We can extract contours - replace them with regular polylines with the AeccSurfaceExtract Objects command. It may be problematic that the contours can have a very complicated shape - numerous "teeth". We can improve this by simplifying the isolines with_Mapclean. What is worth mentioning here is the command WarOpi in the Geolisp program [PONIEWIERA 2017], where by means of one dialog box isolines can be described, simplified, rounded off in several ways, a prefix can be added, etc. Isoline generation dia$\log$ box in Geolisp is shown in Figure 3.

Volume calculation. AutoCAD Civil 3D contains advanced earthwork planning tools: volume calculation, balance of embankments and excavations, earthworks transport chart, cost estimation, etc. A table of volumes is convenient, which we activate/enable with the AeccVolumesDashboard command.

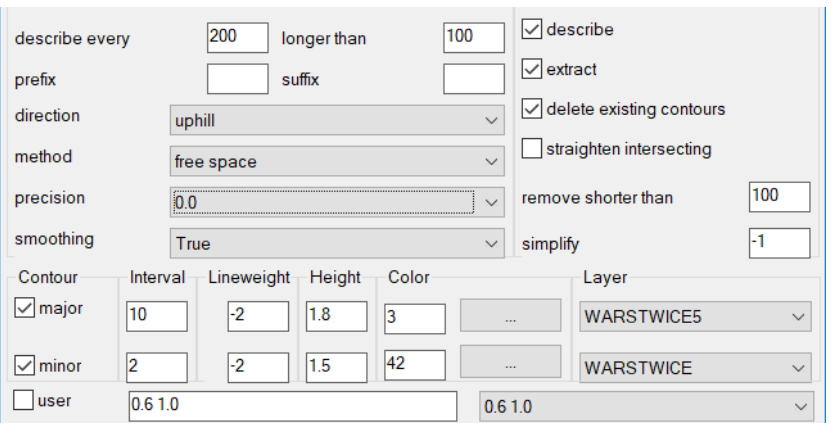

Fig. 3. Isoline generation dialog box in Geolisp; source: own elaboration

\section{TIN SURFACE SIMPLIFYING}

Introduction. Measurement by means of laser scanning usually provides many millions of points, so any analysis based on such large datasets is complicated and long-lasting. Therefore, it is advisable to reduce the number of points and consequently simplify the TIN surface. The problem lies in removing such a large part of the points that the contours do not change. The article presents two methods: the original optimum dataset method [BŁASZCZAK-BĄK et al. 2018] and the AeccSimplifySurface procedure included in the AutoCAD 
Civil program. Both methods work on a slightly different basis. The first one works linearly, directly on the file with measuring points, the other - on the TIN surface. The optimum dataset works much faster and gives very good results without changing the standard program settings. AutoCAD Civil is doing a little better when there are very few points left. Therefore, for typical reductions, for example from a $1,000,000$ to 10,000 , it is better to use the Optimum Dataset method, but when it is necessary to decrease the dataset from a $1,000,000$ to 100 points, it is better to use AutoCAD Civil. Unfortunately, in the latter case, results are not satisfactory and the area will not resemble the original one. More information and some examples are given in the following sections.

Surface simplifying in AutoCAD Civil. Reduction of the number of points can be implemented by following the command: AeccSimplifySurface (this command can also be activated by right-clicking the tool area on Surface Editions). In the dialog box options for removing can be set, for example, $90 \%$ of points, so that the change in the ordinate of neighboring points does not exceed 0.50. The dialog box of Aecc Simplify Surface program is shown in Figure 4.

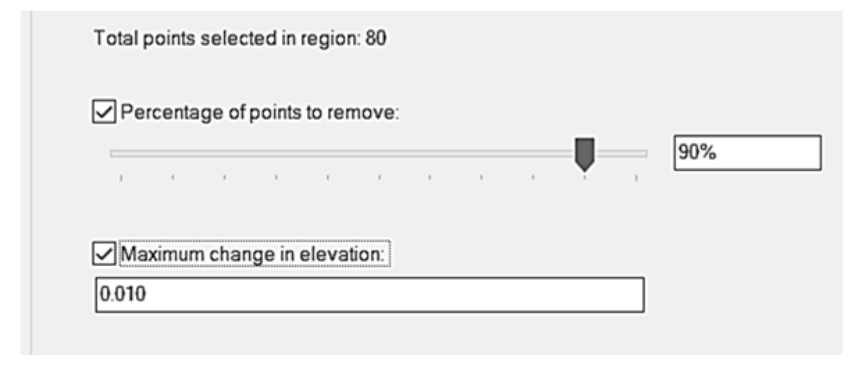

Fig. 4. The options of Aecc Simplify Surface program; source: own elaboration

The Optimum Dataset method. Previous tests have shown that the OptD method gives total control over the number of points in the dataset after the reduction. The OptD method meets all expectations of reducing the size of the dataset without losing the data necessary for the correct execution of the task.

The OptD-single method consists of the following stages [BŁASZCZAK-BĄK 2016]:

Stage 1: Loading $N$ points of the original LiDAR dataset.

Stage 2: Setting up the optimization criterion.

Stage 3: "Fitting" the measurement lines that are the direct result of the measurement into the coordinate system in such a way that the measuring lines are approximately parallel to the $X$ axis or the $Y$ axis.

Stage 4: Projection of the measurement points with LiDAR on the $X 0 Y$ plane.

Stage 5: Determination of the initial width of the measuring strip $L$. Successive values of the measuring strip are determined in the iterative process and change, for example, at a fixed interval.

Stage 6: Division of the area covered by points into measurement strips $(n L)$.

Stage 7: Selection of measuring points for each measuring strip.
Stage 8: Projection of the measurement points from each measuring strip on the $Y 0 Z$ plane.

Stage 9: Selection of the cartographic generalization method. Stage 10: Determination of the tolerance range $(t)$ in the selected generalization method. For the Douglas-Peucker (D-P) method [Douglas, PEUCKER 1973], this is the tolerance interval. The initial value of the segment is set by the user, subsequent values are determined in the iterative process and increase or decrease with every fixed interval.

Stage 11: Application of the selected generalization method in the $Y 0 Z$ plane.

Stage 12: Obtaining a reduced dataset with $M$ points (where $M<N$ ).

Stage 13: Checking whether the dataset obtained in stage 12 meets the initially adopted optimization criterion, if such a reduction process is completed, and the obtained dataset from stage 12 is the optimal dataset. If not, stages 10-12 are repeated, with the value of the tolerance parameter being changed in stage 10 . If repeating stages 10-12 does not solve the problem, return to stage 5 and change the width of the measurement strip.

Stage 14: Record the result in the form of an optimal dataset.

The example of simplifying measurement data. Figure 5 shows isolines and cross-sections of a/the ditch. Figure $5 \mathrm{a}$ visualizes the original dataset containing 2,500,000 points, and in Figure $5 \mathrm{~b}$ it is reduced to a 60,000 dataset. It can be noticed that the method has fulfilled its task and despite a significant reduction in the number of points, calculation like a flow of water can be performed correctly.

\section{RESULTS AND DISCUSSION}

\section{DRAINAGE BASIN}

Introduction. The chapter illustrates how to create a drainage basin in AutoCAD Civil 3D and show the flow of water. The catchment can be created in two ways - at one point or through simultaneous analysis of the whole map [MiODUSZEWSKI 2012; MiODUSZEWSKI et al. 2014].

In both cases, the work should begin by inserting points from the laser scanning into the drawing (as described in chapter "Laser scanning data processing". Then you need to create a TIN surface. In this example, the $O P$ command, available in the Geolisp system, was used. In the program dialog box select the layer on which the points are located, enter the name of the created surface and mark the "create" switch as in Figure 6.

If we have a large number of points from the measurement, it is worth simplifying the surface before creating the basin. Proceed as described in "TIN surface simplifying".

Establishment of water and catch basin at one point. In order to trace the water runoff through the TIN surface, use the "Water run" service program. It can be started by typing the AeccCreateSurfaceWaterDrop command, selecting from the top menu: surfaces - utilities - water runoff ... or on the ribbon: analysis tab, land data panel, flow paths - water runoff. In the "trailing line" dia$\log$ box it is necessary to configure the drawing of water 

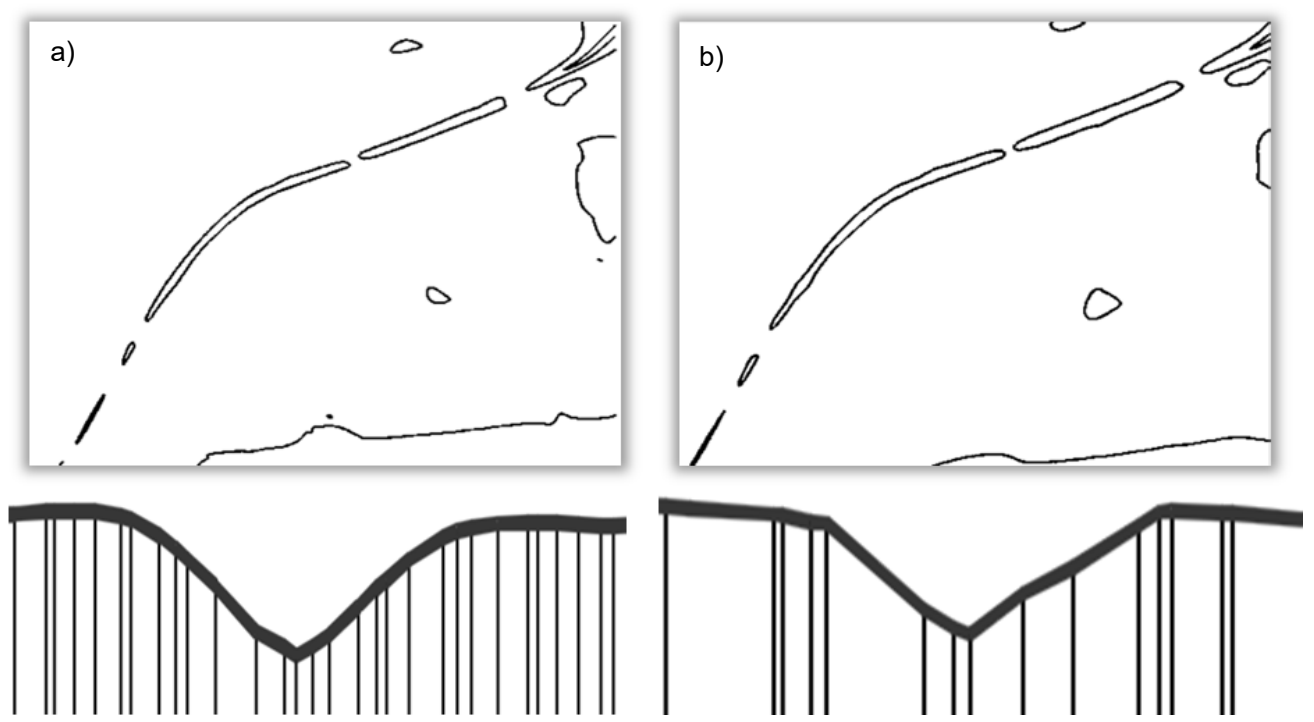

Fig. 5. The example of the operation of the triangular irregular networks (TIN) surface simplifying program; isolines and the cross-section of a/the ditch are shown: a) original dataset $-2,500,000$ points, b) the dataset after applying the OptD method - 60,000 points; source: own elaboration

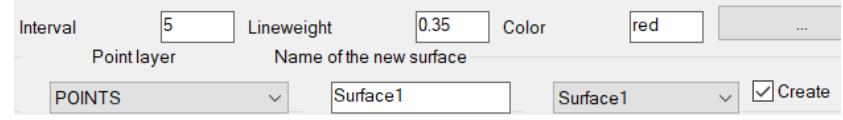

Fig. 6. The Geolisp OP command dialog box; source: own elaboration

drop paths depending on the analysis requirements. After the acceptance, we indicate the point on the surface, thus the beginning of the water drop path is determined. The program will draw a path on which water will move. The water flow will be represented by a 2D or 3D polyline; you can also mark the starting point of the track. In the case when the channel is divided, new polylines will be drawn along each track.

In order to perform a water drainage analysis and display the surface dewatering area, the catchment command was used. You can start them from the top menu (surfaces - utilities - catchment), from the ribbon (analysis tab, data panel about the area, catchment - catchment area) or by entering the AeccCatchmentArea command. The program's operation consists in defining the surface region with the catchment point (the lowest point of depression), enveloping the region with the fence and calculating the catchment area.

The operation of the "water flow" and "catchment" programs is shown in Figure 7. The figure shows the envelope of the catchment area and its field, the depression point and water drop paths determined along contour lines.

Establishing a catchment on the whole map. AutoCAD Civil 3D allows you to perform many types of surface analyses, including contour lines, directions, elevations, slopes, watersheds and water drop paths. In order to perform them, select the type of analysis in the "analysis" tab in the "surface properties" window. Further proceedings depend on the type of the performed analysis.

The watershed analysis is aimed at visualizing and testing the catchment area and is performed on the basis of the TIN line. The program determines the areas through

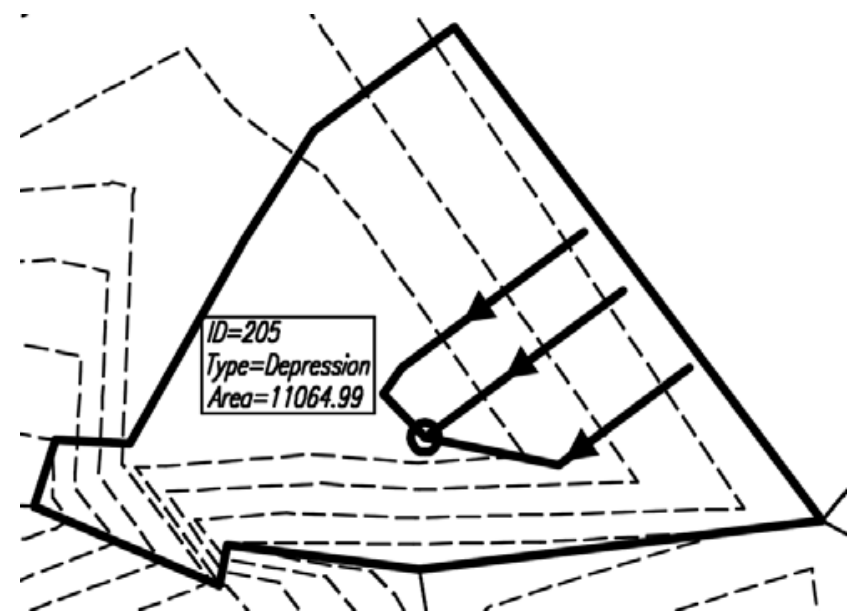

Fig. 7. The flow of water and basin at one point; source: own elaboration

which water should flow over the surface and the location of drainage points and catchment areas. The minimum depth at which the depression in the surface will be considered as a basin (thus a lower depression will not be treated as a catchment) needs to be specified. There is also the possibility of joining adjacent boundary catchments. We get/obtain the analysis in tabular and graphical forms. An exemplary analysis of the catchment is shown in Figure 8.

The control of the correctness of the analysis may be described by the OpNach program. The program will insert a slope block in the center of each TIN triangle. The program window and map fragment with slopes are shown in Figure 9.

\section{CREATING A FORECASTED ALTITUDE MAP}

Preparation of the current relief. The procedure for creating the TIN surface with the current relief will depend on the data we have [PONIEWIERA 2013]. 

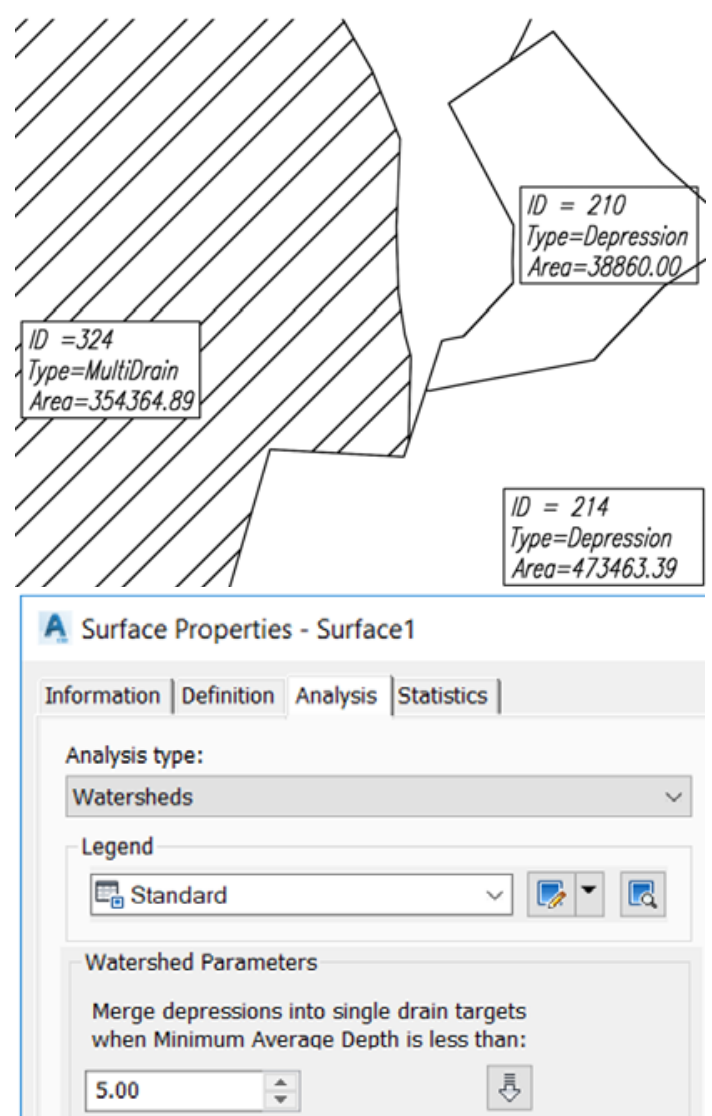

$\checkmark$ Merge adjacent boundary watersheds

Range Details

Type Description Segment Display Area Display

8 Bot Descriptio... Continuous $=\square \times 8 \times$

8 Boเ Descriptio... Continuous = $=0$

Fig. 8. Analysis of the catchment; source: own elaboration

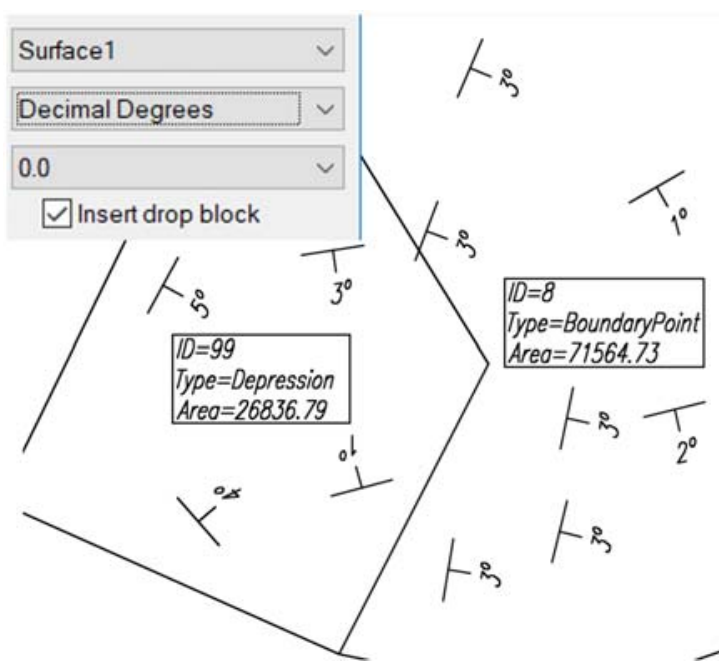

Fig. 9. Inserting drop blocks using the OpNAch command; source: own elaboration
The TIN surface depicting the current terrain relief is most accurately and quickly created on the basis of the data from the direct measurement. In the created TIN surface you should take into account: pickets, breaklines and possibly boundaries of the area. In addition, you can create a TIN surface by measuring the water level in wells.

If the TIN surface is to be created on the basis of analogue situational and altitude maps, they should be scanned, calibrated and then the selected objects should be vectorized (height benchmarks, contour lines, major edges of escarpments). It is important that the objects inserted into the drawing have a correctly defined elevation. We create the TIN surface and add to it successively the altitude points, breaklines and contour lines.

You can use digital altitude maps to create a TIN surface. On these maps, the objects are already vectorized they should be added to the created surface in the manner described above. However, broken contours that do not have a fixed elevation altitude might pose a problem. In order to add them to the surface, they should be given a correct elevation, e.g. using the ZnWarl command from Geolisp.

Often the curve showing contours has a very large number of vertices. Adding such a line to the surface would complicate it, which is why it should be simplified using the AutoCAD Civil 3D MapClean command (the option "Simplify objects"). Broken contours can be combined into one object by selecting the "Dissolve Pseudo Nodes" option.

Generating the forecasted altitude map. Having a file with the current measuring points, we often calculate their coordinates after the end of exploitation and based on these points we create the predicted surface of the TIN. The procedure of creating is the same as in the case of creating a TIN surface showing the current terrain relief based on the measurement data.

However, if we already have a created numeric map, with contour lines, benchmarks etc., it is more convenient to calculate the predicted reductions with the help of the EDN program. The file current map.grd created as a result of the program's operation, which includes a predicted decrease in the area of each square of mesh, can be then imported into the drawing using the Read-Grd command, simultaneously creating the TIN surface of the depressions.

The forecasted altitude map is implemented in three stages:

- projection of the map objects (benchmarks, contour lines, breaklines) to the created depression area to obtain the size of deformation of individual map elements;

- subtracting the values from the ordinates of these objects to obtain the forecasted heights;

- creation of a new TIN surface showing the forecasted altitude map.

MWys program from the Geolisp system enables the creation of a new TIN surface by subtracting two surfaces: one - presenting the current area and the other - depicting the depression. When creating a surface, descriptions of benchmarks are updated and new contour formations with descriptions are created. 
Detection of floods on streams. In order to determine overflows on streams, the following steps should be performed:

- we measure the bottom of the stream and cross-sections for the most important watercourses (we will get the height of the water surface and slopes);

- we calculate the predicted position of points in programs calculating deformations or in AutoCAD (if we have created a TIN surface reduction);

- we create a graph for the forecasted stream (e.g. using the Geolisp program command); Figure 10 shows the impact of exploitation on the course of the stream, the area above the mining wall is lowered, there is a natural dam that causes a rise in the water level; in the graph, apart from the bottom of the stream, places where the water level is higher than the surrounding slopes or approaching the summit of slopes are marked;

- we set the scope of the floodplain (how wide it will spill). It is depicted by a contour with an ordinate equal to the height of the breakthrough point in the graph. It can be created using Geolisp tools (OP command, enter the desired value in the "jump" field) or AutoCAD Civil 3D (in the "surface properties" window, on the "analysis" tab, select "User-defined layers").

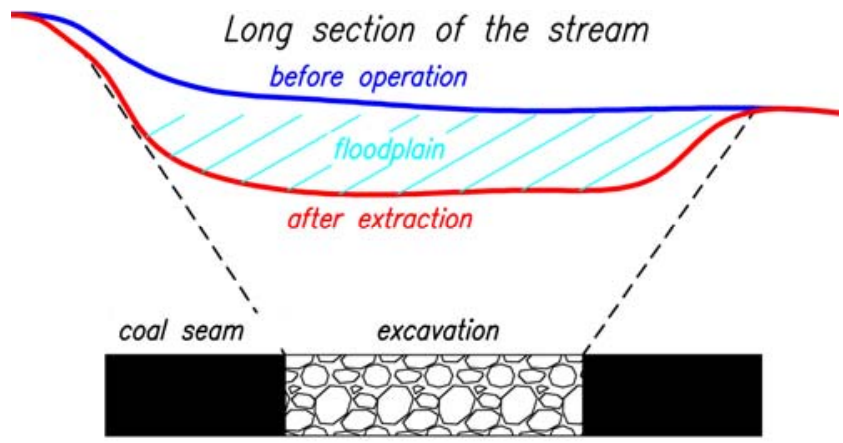

Fig. 10. The impact of exploitation on the course of the stream; source: own elaboration

We extract a contour from the TIN surface (e.g. by using the $O P$ command (the "extract and describe contours" option) or AeccSurfaceExtractObjects option) and we circle the area in which the floodplain will be formed.

Lowering below the aquifer. As a result of mining exploitation, water relations change - floodplains can be formed in places where the water surface is above the ground/terrain surface. We designate them by subtracting the TIN surface of the existing water surface from the projected surface area ( $m W y s$ command in the Geolisp system).

Figure 11 shows a fragment of the area with brown contours marked on the basis of the current measurement. Next, the predicted decrease in land caused by the planned exploitation was calculated. Reductions are shown in blue isolines. By adding a reduction to the current surface, we obtain a forecasted height map. The red isolines show the distance of the current water table to the projected surface. Where isolines are positive means that water can be above the site, this area has been hatched blue.

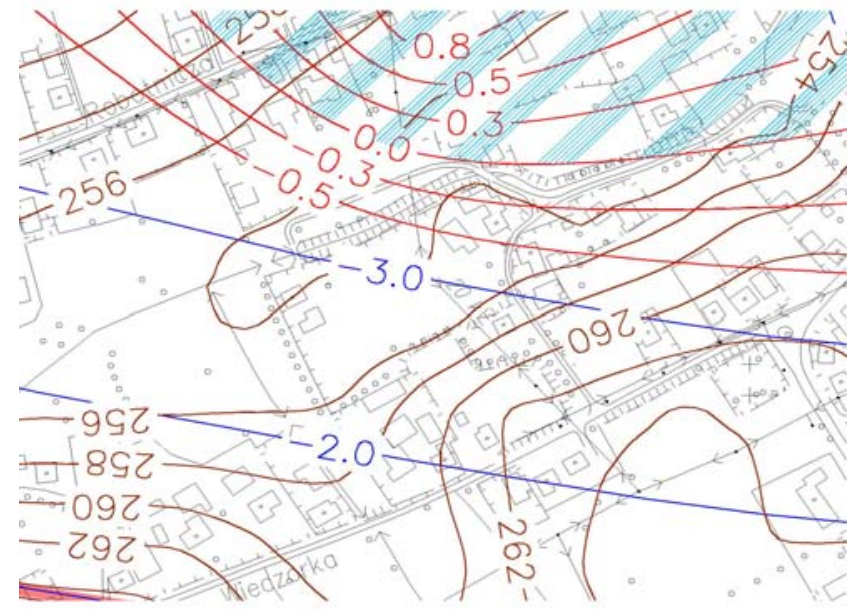

Fig. 11. The impact of exploitation aquifer; the red isolines show the distance of the current water table to the projected surface; where isolines are positive means that water can be above the site, this area has been hatched blue; source: own elaboration

In order not to let a flood occur, it is necessary to place a pumping station in a suitable place, which will forcefully remove excess water.

Finding closed areas. The out-of-flow depression of the terrain, i.e. the area from which water does not have any possibility to flow into a different region, from a geometric point of view, is created by each closed contour surrounding the lower ordinate. Its creation is influenced by, among others, the type of soil and the height of the aquifer. Areas particularly exposed to flooding can be determined by following the method described below.

In the Geolisp system, non-drainage areas can be found using the STB command - the program scans them. With the outlining of closed out contours (closed polylines), we perform a topology using the Topo (Geolisp) or MapTopoCreata (AutoCAD MAP) command. Then, with the help of a closed polyline, we mark the areas of impermeable soils and create a topology for them. Having created two topologies, we find their common part. This can be done using the TopoI (Geolisp) or MapAnOverlay command - type of analysis - product (AutoCAD Map).

Applying isolines of deformation to the map. The current_map.plt file, containing the isolines of parameters, is created in the EDN program, in the c: $\backslash$ Edn $\backslash$ Pro $\backslash$ Working directory. While working in the EDN program, it is recommended to activate only one type of objects at a time (e.g. only isolines of depressions, no points, buildings, etc.), because the program places all objects on one layer.

We can insert objects from the current_map.plt file using the Read_Plt command to the AutoCAD drawing. It is important to choose the appropriate layer on which the isolines will be drawn, especially in the case of deformations - depending on the category of deformation, the program selects the appropriate (according to the standard) color of the isolines. Red objects (color no. 1 according to the AutoCAD color index (ACI)) are treated by the program as a frame (therefore it should not be used for other objects), the coordinates of the frame corners are downloaded from the file, or manually entered. There is 
a Granica command that reads the border file - with objects in the EDN format.

\section{CONCLUSIONS}

Mining exploitation changes water conditions and causes a reduction in the area, which may lead to flooding. If it is possible, the excess of water is drained in a gravitational manner. If not, then the pumping station is used. It should be located in the place where the largest amount of water goes and where the floodplain is most likely to occur. The article presents the possibilities of using AutoCAD Civil 3D and Geolisp to find the optimal location of the pumping station for the mining area of Krzyżowice III Coal Mine "Pniówek". The issue of importing point cloud file, point cloud stylization as well as creating TIN surface from such source data was discussed here. A particular attention was paid to the issue of TIN surface simplifying by means of both the AutoCAD tools and the proprietary Optimum Dataset method. It can be said that the OptD method removes from the dataset with measured points those points that do not significantly change the course of isolines.

In AutoCAD Civil 3D there is workflow showing the surface water runoff. The paper presents two ways to create a catchment - at one point and through simultaneous analysis of the entire map.

While determining the location of pumping stations in mining areas, it is necessary to take into account not only the current terrain, but the entire life of the mine. Therefore, it is necessary to make a forecasted height map. The article describes how to create it using AutoCAD Civil 3D, Geolisp and EDN.

Finding the optimal location of the pumping station for OG Krzyżowice began with the implementation of the numerical terrain model in AutoCAD Civil 3D. Its creation was based on data obtained from laser scanning. The number of points defining the TIN surface - about 220,000,000 points, has been reduced to around 100,000 , and thus the surface has been simplified. The original points remained in the model but were not used in the triangulation of the surface. The next step was the division of the basin for the Krzyżowice III mining area based on the forecasted relief. As a result of this operation, the places to which water flows were indicated. There was already a pumping station in this area and as a result of the analysis it was found out that despite the planned operation, it is not necessary to change its location.

The advancement of technology involving the development of a predicted mining surface area based on the Digital Model requires many further studies. However, many practical problems have already been solved and presented in this article by the authors.

\section{REFERENCES}

BiAŁEK J. 2003. Algorytmy i programy komputerowe do prognozowania deformacji terenu górniczego [Algorithms and computer programs for forecasting mining area deformations]. Gliwice. Wydaw. PŚl. ISBN 8373350640 pp. 199.

BŁASZCZAK-BĄK W. 2016. New Optimum Dataset method in LiDAR processing. Acta Geodynamica et Geomaterialia. Vol. 13. No. 4(184) p. 379-386. DOI 10.13168/AGG.2016.0020.

BŁASZCZAK-BĄK W., PONIEWIERA M., SOBIERAJ-ŻlobiŃSKa A., KowALIK M. 2018. Reduction of measurement data before DTM generation vs. DTM generalization. Survey Review. DOI 10.1080/ 00396265.2018.1474685.

Douglas D.H., PeuCKer T.K. 1973. Algorithms for the reduction of the number of points required to represent a digitized line or its caricature. Canadian Cartographer. Vol. 10. Iss. 2 p. 112-122. DOI 10.1002/9780470669488.ch2.

GEO-LISP 2018. System obsługi kopalnianych map numerycznych [Digital Mine Maps Management System Geolisp] [online]. [Access data: 2018.03.01]. Available at: www.geolisp.pl

Gharbi M., Soualmia A., Dartus D., Masbernat L. 2016. Comparison of 1D and 2D hydraulic models for floods simulation on the Medjerda River in Tunisia. Journal of Materials and Environmental Science. Vol. 7. Iss. 8 p. 3017-3026.

HARTNETT M., NASH S. 2017. High-resolution flood modeling of urban areas using MSN_Flood. Water Science and Engineering. Vol. 10. Iss. 3 p. $175-183$. DOI 10.1016/j.wse.2017.10. 003 .

Jelonek I., Poniewiera M., GĄSior B. 2015. The qualitative model of the deposit on the example of the Kompania Weqglowa S.A. P. I: Stages in the development of the digital model the deposit. Potsdam, Germany. Schriftenreihe der Deutschen Gesellschaft für Geowissenschaften. H. 87 p. 91.

KUZIA K. 2016. Application of airborne laser scanning in monitoring of land subsidence caused by underground mining exploitation. Geoinformatica Polonica. Vol. 15 p. 7-13.

MiodUSZEWSKI W. 2012. Small water reservoirs - their function and construction. Journal of Water and Land Development. No. 17 p. $45-52$.

Mioduszewski W., Querner E. P., Kowalewski Z. 2014. The analysis of the impact of small retention on water resources in the catchment. Journal of Water and Land Development. No. 23 p. 41-51. DOI 10.1515/jwld-2014-0028.

PONIEWIERA M. 2013. Model terenu górniczego [Model of mining area]. Przegląd Górniczy. T. 69. Nr 8 p. 176-179.

PONIEWIERA M. 2017. Zastosowanie oprogramowania Geolisp do budowy dynamicznego systemu informacji o przestrzeni górniczej [The use of the Geolisp software to build a dynamic information system about the mining area]. Systemy Wspomagania w Inżynierii Produkcji. Vol. 6. Iss. 3 p. 213-222.

SOKOŁA-SzEwiołA V., WiAtR J. 2014. The spatial digital inventory of mining plant objects using terrestrial laser scanning technology. In: Innovative technologies in mining and transport. Ed. A.W. Korczak. Katowice, Moscow. Publishing House of Silesian University of Technology p. 56-70. 


\section{Marian PONIEWIERA, Iwona JELONEK, Wioleta BLASZCZAK-BĄK}

\section{Optymalne umiejscowienie pompowni na podstawie numerycznego modelu terenu}

\section{STRESZCZENIE}

Celem pracy było znalezienie optymalnego umiejscowienia pompowni dla obszaru górniczego Krzyżowice III Kopalni Węgla Kamiennego „Pniówek”. Eksploatacja górnicza powoduje obniżenie terenu i zmianę stosunków wodnych. Stąd konieczność wykonania grawitacyjnego, a jeżeli to niemożliwe, wymuszonego odpływu wody. Konieczne stało się więc znalezienie takiego miejsca dla pompowni, żeby usunąć nadmiar wody i nie dopuścić do powstania zalewiska. Należało uwzględnić nie tylko aktualną rzeźbę terenu, ale cały okres życia kopalni. Na podstawie posiadanego lotniczego skaningu laserowego wykonano numeryczny model terenu. Następnie wykonano podział na zlewnie całego przedmiotowego obszaru. W artykule przedstawiono proces wykonania symulacji, jak teren będzie się zmieniał wskutek prognozowanej eksploatacji górniczej. Dodatkowo podano praktyczny sposób rozwiązania problemu upraszczania dużej ilości danych. Uzyskane materiały źródłowe zostały opracowane za pomocą oprogramowania Geolisp. System ten działa w środowisku graficznym CAD i pozwala na automatyzację najczęściej wykonywanych prac z zakresu opracowywania map górniczych. Geolisp współpracuje z programem EDN-OPN. Dzięki temu możliwe jest połączenie uzyskanych wyników obliczeń prognozowanych deformacji obszaru górniczego i górotworu z mapą numeryczną.

Słowa kluczowe: AutoCAD Civil, deformacja terenu górniczego, numeryczny model terenu, skaning laserowy 